\title{
A two-step approach to qPCR experimental design and software for data analysis
}

\author{
Huazhang Guo*, Larry Tague, Ramesh Ray, Gabor Tigyi \\ From UT-ORNL-KBRIN Bioinformatics Summit 2010 \\ Cadiz, KY, USA. 19-21 March 2010
}

\section{Background}

The quantitative polymerase chain reaction ( $\mathrm{qPCR}$ ) is a widely used sensitive method for measuring gene expression, especially for low levels of mRNA. Currently, qPCR has no standard guideline for experimental design and statistical analysis. We have developed a two-step experimental design that uses screening and confirmation steps.

\section{Materials and methods}

For screening, a single biological sample is used for each control and treatment group. If screening shows interesting findings, confirmation follows with more biological replicates and a definitive statistical analysis using pooled data from the screening and confirmation steps. This experimental design for qPCR reduces reagent cost and labor without sacrificing sensitivity. To quantitate gene expression, we selected the comparative $\mathrm{Ct}$ method due to its simplicity, intuitiveness, and popularity. For statistical analysis, however, this two-step approach raised an interesting question; which parameter should be used for statistical analysis of the data from the screening step. With a single biological sample, the statistical analysis relies on the technical replicates of qPCR. Even though it is natural to assume a normal distribution of the relative gene expression levels of biological replicates based on the central limit theorem, it is unknown for technical replicates because the $\mathrm{Ct}$ values of the technical replicates have been non-linearly transformed to obtain relative gene expression levels. Hence, we studied the distribution of delta-Ct and relative gene expression levels from our qPCR data and found that the distribution of delta-Ct is symmetrical and approximately normal while the distribution of relative gene

\footnotetext{
* Correspondence: huazhang.guo@gmail.com

Department of Physiology, University of Tennessee Health Science Center, Memphis, TN 38163, USA
}

expression levels is skewed. Therefore, we chose delta$\mathrm{Ct}$ as our parameter for statistical analysis of the technical replicates from the screening step. To automate the data analysis of the screening step, we developed REALPLOT. A text file is used to enter $\mathrm{Ct}$ values and gene/ group information into REALPLOT that calculates relative gene expression, performs statistical analysis, and graphically displays the screening step data. To automate the data analysis after the confirmation step, we developed REALPOOL that pools the data from both the screening and confirmation steps, performs the final statistical analysis, and generates a publishable graphical representation. REALPLOT and REALPOOL were developed using the open-source statistical $R$ environment. They are compatible with all major computer operating systems.

Published: 23 July 2010

doi:10.1186/1471-2105-11-S4-P18

Cite this article as: Guo et al:: A two-step approach to qPCR

experimental design and software for data analysis. BMC Bioinformatics 2010 11(Suppl 4):P18.

Submit your next manuscript to BioMed Central and take full advantage of:

- Convenient online submission

- Thorough peer review

- No space constraints or color figure charges

- Immediate publication on acceptance

- Inclusion in PubMed, CAS, Scopus and Google Scholar

- Research which is freely available for redistribution

Submit your manuscript at www.biomedcentral.com/submit

C Biomed Central 